\title{
Isolation and Characterization of Plant Growth- Promoting Bacillus amyloliquefaciens Strain sks_bnj_1 and its Influence on Rhizosphere Soil Properties and Nutrition of Soybean (Glycine max L. Merrill)
}

\author{
Sushil K. Sharma ${ }^{1}$, Aketi Ramesh ${ }^{1}$ and Bhavdish N. Johri ${ }^{2}$ \\ ${ }^{1}$ Directorate of Soybean Research (ICAR), Khandwa Road, Madhya Pradesh, India \\ ${ }^{2}$ Department of Biotechnology and Bioinformatics Centre, Barkatullah University, \\ Madhya Pradesh, India
}

Correspondence should be addressed to: Sushil K. Sharma; sks_micro@rediffmail.com

Received 20 January 2013; Accepted 25 February 2013; Published 23 April 2013

Academic Editor: Rosario Azcón

Copyright @ 2013 Sushil K. Sharma, Aketi Ramesh and Bhavdish N. Johri. Distributed under Creative Commons CC-BY 3.0

\begin{abstract}
The objective of this work was to isolate and characterize Bacillus bearing multiple plant growthpromoting traits from diseased roots of soybean and to further assess its inoculation effect on soil rhizosphere properties and nutrition in soybean. The isolate was putatively identified as Bacillus on the basis of cultural characteristics and FAMEs profile, and further sequencing of $16 \mathrm{~S}$ rRNA gene revealed $98.7 \%$ similarity to Bacillus amyloliquefaciens and designated as strain sks_bnj_1 (AY 932823). The strain possessed multiple plant growth-promoting traits such as siderophore production, indole-3-acetic acid-like-compounds, ACC deaminase, phosphatases, phytases, HCN, cellulases, zinc solubilization and antagonisms to soil-borne pathogens. Microcosm study using soybean as an indicator crop revealed that inoculation of this strain sks_bnj_1 significantly increased rhizosphere soil properties (enzyme activities, IAA production, microbial respiration, microbial biomass- $\mathrm{C}$ ), and nutrient content in straw (K, $\mathrm{P}, \mathrm{Zn}, \mathrm{Fe}, \mathrm{Cu}, \mathrm{Mn}$ ) and seeds $(\mathrm{K}, \mathrm{P}, \mathrm{Fe}, \mathrm{Mn})$ of soybean over un-inoculated control. This study suggests that inoculation of B. amyloliquefaciens sks_bnj_1 improves most of the rhizosphere properties, plant growth, nutrient assimilation and yield of soybean and has potential to be promoted as a bioinoculant for soybean production following proper field evaluation.
\end{abstract}

Keywords: Bacillus; plant growth-promoting traits; soil enzyme activity; soybean.

\section{Introduction}

Soybean has now established itself as a major oilseed crop in the rain-fed agroecosystems of India. The limited area of 0.03 $\mathrm{m}$ ha in 1970 is now scintillating around 10 $m$ ha (Dupare et al, 2010). Despite phenomenal growth in area, it has been a matter of great concern that in spite of high yield achieved in demonstrations under real farm conditions (average $1800 \mathrm{~kg} \mathrm{ha}^{-1}$ ), the national productivity still remains around

Cite this Article as: Sushil K. Sharma, Aketi Ramesh and Bhavdish N. Johri (2013), " Isolation and Characterization of Plant Growth-Promoting Bacillus amyloliquefaciens Strain sks_bnj_1 and its Influence on Rhizosphere Soil Properties and Nutrition of Soybean (Glycine max L. Merrill)," Journal of Virology \& Microbiology, Vol. 2013 (2013), Article ID 446006, DOI: 10.5171/2013.446006 
$1000 \mathrm{~kg} \mathrm{ha}^{-1}$ (Bhatia et al, 2008). Soybean is predominantly grown in Vertisols and associated soils and is prone to soil physicochemical and biological degradation. These soils are potentially productive, if managed properly in terms of overcoming soil water and nutrient management constraints. Paradoxically, the farmers either do not generally adopt fertilizer recommendations or resort to imbalanced fertilization. Further, low native soil nutrient availability and use efficiency of applied nutrients are two other major impediments to fulfill nutrient requirements to crops. Consequently, large inputs of mineral fertilizers are required to be added to soil to meet the nutrient needs of crops. Since the farmers are largely cash-limited and fertilizers being costly, it is pertinent to develop production systems that are nutrient efficient. Moreover, continual application of chemical fertilizers along with pesticides is known to have detrimental impact on soil health (Correa et al, 2009). Therefore, to improve soybean productivity without deteriorating soil quality the plausible way is through the adoption of appropriate improved natural resource management strategies. In recent years, there has been a paradigm shift with evolving interest in the use of biological approaches, as an alternative to chemical fertilizers, to improve crop productivity and plant resistance to phytopathogens (Rosas et al, 2009; Dasatger et al, 2011). In this context, there is a considerable interest worldwide in the use of beneficial rhizosphere microorganisms as bioinoculants and to harness the potential of beneficial plant-microbe-soil interactions to increase the availability of nutrients for crop assimilation (Jacobsen et al. 2005; Berg 2009). Microbial populations are key components of the soil-plant continuum where they are immersed in a framework of interactions affecting plant development (Barea et al, 2005). There are several groups of beneficial rhizosphere microorganisms including soil bacteria which are usually referred to as plant growth-promoting rhizobacteria (PGPR) (Kloepper et al, 1989), but subsequently Bashan and Holguin (1998) coined a new terminology namely 'plant growth-promoting bacteria'(PGPB) for those which were isolated from the plant parts other than rhizosphere. These include genera such as Acinetobacter, Acetobacter, Alcaligenes, Arthrobacter, Azospirillum, Azotobacter, Bacillus, Beijerinckia, Burkholderia, Enterobacter, Erwinia, Flavobacterium, Gluconacetobacter, Pantoea, Pseudomonas, Ralstonia, Rhizobium, Serratia, etc. (Hayat et al, 2010; Sharma et al, 2011). Among bacteria, species belonging to Bacillus play an important role in the agroecosystems as this bacterium helps in improving plant growth and nutrient assimilation (Ramirez and Kloepper, 2010). Plant growth-promotion by rhizosphere bacilli is a consequence of combined effects of different mechanisms such as production of 3-hydroxy-2-butanone (acetoine), 2,3butanediol, IAA, phytase, lipopeptide, polyketide, siderophore and induced systemic resistance (Koumoutsi et al, 2004; Idriss et al, 2007; Zhao et al, 2011). The effectiveness of microorganisms in influencing nutrient mobilization and assimilation by crop plants can only be gauged by studying the changes in the rhizosphere properties such as microbial biomass, soil enzymes, auxin (IAA-like compounds) production etc. and this gives a comprehensive view of the impact of an inoculants on the ecosystem functioning (Caravaca et al, 2003; Sharma et al, 2011). However, a relatively few studies of this nature have been conducted to involve such parameters as methods to monitor the effects of inoculation (Kohler et al, 2007; Sharma et al, 2011). It has been reported that Bacillus subtilis increased enzyme activities and assimilation of nutrients such as foliar P and $\mathrm{K}$ contents of Lactuca sativa (Kohler et al, 2007).

So far a few species of Bacillus with limited PGP traits have been isolated from rhizosphere of soybean cultivated in soils of central India that helped in improving nutrition and productivity of soybean (Ramesh et al, 2011; Sharma et al, 2012). However, no information is reported so far on the occurrence of soybean rhizosphereassociated Bacillus bearing multitude of plant growth-promoting traits from soils of this region. The hypothesis of this study is to isolate Bacillus bearing multifarious PGP traits that has ability to improve rhizosphere soil properties, nutrition and yield of soybean. The specific objectives were: (1) isolation and characterization of 
antagonistic Bacillus isolate from diseased root of soybean (2) assessment of plant growth-promoting traits of the isolate (3) to assess changes in rhizosphere soil properties, nutrition and yield of soybean upon its inoculation.

\section{Materials and Methods}

\section{Experimental Site and Isolation of Bacterium}

The roots of soybean cv Gaurav infected with black complex disease were uprooted from an experimental field (Sarol series, Vertisol) located at Research Farm, Directorate of Soybean Research, Indore, Madhya Pradesh, India (220 8' N latitude; $75^{\circ} 4$ 'E longitude and at an altitude of $560 \mathrm{~m}$ above mean sea level) during kharif season (rainy season, June - Sept) of 2004 in order to isolate fungal pathogens associated with diseased roots. To isolate associated pathogens, diseased roots were placed in sterilized tubes and surface sterilized with 95\% ethanol for 1 min followed by washing in $3 \%$ sodium hypochlorite and finally 5 rinses in sterile distilled water. After sterilization, small root bits were placed on potato dextrose agar (PDA; Himedia, Mumbai, India) plates which were incubated at $30^{\circ} \mathrm{C}$ for $72 \mathrm{~h}$. During isolation, an antagonistic bacterium also appeared along with pathogenic fungi on PDA. This bacterium was picked and subsequently allowed to grow on nutrient agar medium (Himedia, Mumbai, India) for characterization. This method of isolation of beneficial bacteria using PDA from diseased roots is not a conventional approach. The isolated rhizobacterium was stored as glycerol stock at $-80^{\circ} \mathrm{C}$.

\section{Characterization and Identification of Bacterium}

The bacterial culture was characterized phenotypically to the genus-level based on its colony morphology (size, margin, elevation, pigmentation), microscopic observation (Gram's and endospore staining), physiological tests $(\mathrm{pH}$, temperature sensitivity and salt tolerance) and biochemical tests (catalase, oxidase, nitrate reduction, IAA production, arginine dihydrolase, starch hydrolysis, casein hydrolysis, Voges Proskauer, citrate utilization, triple sugar iron agar, methyl red) by adopting standard procedures (Holt et al., 1994). Carbon source (C-source) utilization by the strain was carried out in M9 minimal medium containing specific carbohydrates (Amarger et al, 1997).

\section{Whole Cell Fatty Acid Analysis}

The putative bacterial isolate was subjected to whole-cell fatty acids methyl esters (FAMEs) profiling for further confirmation of its identity. The whole-cell cellular fatty acids of the bacterial isolate was derivatized to methyl ester and resultant extract passed through GC (Agilent Technologies, Model 7890A) equipped with an 7683 series autosampler and 7683 B series injector, FID, HP-Ultra 2 fused silica capillary column of $25 \mathrm{~m} \times 0.2 \mathrm{~mm} \times 0.33 \mu \mathrm{m}$. The hydrogen as the carrier gas, nitrogen as the "make up" gas, and air to support the flame were used. The operating temperature of injector and detector were set at $250^{\circ} \mathrm{C}$ and $300^{\circ} \mathrm{C}$, respectively, while GC oven (column) temperature programmed from 170 to $270^{\circ} \mathrm{C}$ with $5^{\circ} \mathrm{C}$ increase per minute up to $300^{\circ} \mathrm{C}$ and held at $2 \mathrm{~min}$ at this temperature. The fatty acids were identified and quantified by comparison with the retention times and peak areas obtained for the authentic standard fatty acid mixture (Sigma). Fatty acid profiles were compared with the profiles in the Sherlock bacterial fatty acid reference library RTSBA6 6.10 of MIDI, Inc., Newark, DE, USA (Kunitsky et al, 2006).

\section{Molecular Characterization}

Bacterial genomic DNA was extracted by adopting the cetrimonium bromide (CTAB) method as described by Bazzicalupo and Fani (Bazzicalupo and Fani, 1995). The gene-encoding 16S rRNA was amplified from genomic DNA of the selected bacterial isolate by the polymerase chain reaction (PCR, Thermal Cycler PTC-200, M.J. Research) using Taq DNA polymerase and bacterial universal primers Gm3f (5' GGT CTG AGA GGA TGA TCA AGT 3') and Gm4r (5'TTA GCT CCA CCT CGC GGC 3'). The 16S rRNA gene amplicon was subjected to partial sequencing using the dideoxy chain termination method utilizing big dye 
terminator ready reaction mix (Applied Biosystems). Sequencing reaction product was analysed by capillary electrophoresis with ABI PRISM 310 Genetic Analyzer. The BLAST database of National Centre for Biotechnology Information (NCBI) (http://www.ncbi.nlm.nih.gov) was used to compare the sequence of bacterium with known 16S sequences in the existing database and identified as Bacillus amyloliquefaciens (Accession No. AY932823) (Altschul et al, 1997).

\section{In Vitro Detection of Plant Growth Promoting Traits of B. amyloliquefaciens Strain sks_bnj_1}

B. amyloliquefaciens strain sks_bnj_1 was assayed qualitatively for siderophore production by spot inoculation of the culture on chrome azurol S (CAS; Acros Organics, Geel, Belgium) agar medium. The development of yellow to orange halo around the bacterial colony after incubation at $28^{\circ} \mathrm{C}$ for 4 days against a blue background indicated siderophore production (Schwyn and Neilands, 1987). For quantitative estimation of siderophore production by the bacterium, CAS shuttle solution assay was followed as described by Payne (1994). To identify a suitable growth medium for enhanced siderophore production, three base growth media such as PDA, King's B medium and nutrient agar (NA) were supplemented with CAS and size of halo formation was recorded. The Overlay-CAS (O-CAS) agar assay was performed to detect chemical nature of siderophore production by the bacterium (Perez-Miranda et al, 2007). The chemical nature of siderophores was further confirmed by growing the bacterial culture in Fiss-minimal broth under iron stressed condition. The culture supernatant was subjected to Atkin's assay, $\mathrm{FeCl}_{3}$ assay and tetrazolium test to detect hydroxamate type siderophore, while Arnow's test and $\mathrm{FeCl}_{3}$ test with a peak at 495 was assessed for catecholate type siderophore (Baakza et al, 2004). Production of indole-3-acetic acid (IAA)-like compounds by the bacterium in nutrient broth supplemented with L-trytophan (200 $m g \quad \mathrm{~L}^{-1}$ ) was determined as described by Gordon and Weber (1951) using Salkowski's reagent $\left(0.5 \mathrm{M} \mathrm{FeCl}_{3}\right.$ prepared in $35 \%$ perchloric acid).
The ACC (1-aminocyclopropane -1carboxylate) deaminase production was detected qualitatively by growing test bacterium on Dworkin and Foster (DF) minimal salts (Dworkin and Foster, 1958) supplemented with $3 \mathrm{mM}$ ACC (Acros Organics, Geel, Belgium) following the standard protocol. The growth of the bacterial strain on DF medium contacting ACC is indicative of ACC deaminase production. Quantitative determination of ACC-deaminase production by test bacterium was performed by determining the amount of ammonia generated by enzymatic hydrolysis of ACC (Jacobson et al, 1994). The protein content in the supernatant was measured using the method of Bradford (1976). ACC deaminase activity was expressed as the amount of ammonia released per $\mathrm{mg}$ of protein per hour.

Acid- (EC 3.1.3.2) and alkaline- phosphatase (3.1.3.1) activities in nutrient broth inoculated with bacterial strain were determined following the procedure of Tabatabai (1994). The phosphatase activity was expressed in pico Katal (pKat) $\mathrm{ml}^{-1}$. One pKat is the amount of enzyme required to hydrolyse 1.0 picomol of substrate per second at specific $\mathrm{pH}$ and temperature.

The bacterial strain was grown in phytate screening broth (Kerovuo et al, 1998) supplemented with $4 \mathrm{~g} \mathrm{~L}^{-1}$ Ca-phytate as sole $\mathrm{P}$ source. The liquid culture was incubated at $28^{\circ} \mathrm{C}$ in an orbital shaker for 2 days at $130 \mathrm{rpm}$ at $28^{\circ} \mathrm{C}$. After incubation, the culture was centrifuged at 7,000 $\mathrm{g}$ for 10 min and filtered through Whatman No 42 filter paper. The clear supernatant was used for quantitative assay of phytase activity by adopting the standard procedures (Ames et al, 1966; Baruah and Barthakur, 1999). The phytase activity was expressed in pKat $\mathrm{ml}^{-1}$.

The zinc solubilizing ability of the strain was carried out according to the protocol described by Fasim and co-workers (2002). Hydrogen cyanide (HCN) production by the bacterial strain was assayed qualitatively as described by Bakker and Schipper (1987). Bacterial culture grown in nutrient broth were spot inoculated on M9 minimal agar medium supplemented with $0.2 \%$ carboxymethylcellulose and $0.5 \%$ tryptone 
(Teather and Wood, 1982) to test its ability to produce cellulase. The bacterial strain was tested for antagonism against Sclerotium rolfsii, Fusarium nivale MTCC7111 and Sclerotinia spp MTCC7114 isolated from diseased soybean plants at Directorate of Soybean Research, Indore. The pathogens were grown on PDA at $28^{\circ} \mathrm{C}$ for dual culture bioassay. The bacterial strain was grown in nutrient broth and incubated for $24 \mathrm{~h}$ and was spot inoculated at equidistant from the edge of the Petriplate containing PDA and NA (1:1 ratio) and then allowed for further growth for $48 \mathrm{~h}$ at $28^{\circ} \mathrm{C}$. A $5.0 \mathrm{~mm}$ disc of appropriate fungal pathogen was placed in the centre of the plate inoculated with bacterial culture. Inhibition of fungal mycelium around bacterial colonies is an indication of antagonistic trait. The inoculated and un-inoculated (without bacterium) plates were incubated at $28^{\circ} \mathrm{C}$ for 5-7 days and inhibition zone was measured.

\section{Microcosm Experiment}

Soil samples for microcosm study was collected from Research Farm, Directorate of Soybean Research, Indore, India and passed through a 2-mm sieve before filling the pots. Soil sample was also subjected to analyses of pertinent physico-chemical and microbial parameters. The soil belongs to sarol series (isohyperthermic, montmorollinitic, typic haplusterts) with the following characteristics: $\mathrm{pH}$ 8.03, electrical conductivity $0.18 \mathrm{dS} \mathrm{m}^{-1}$, sand 11.3 $\%$, silt $32.2 \%$, clay $56.5 \%$, organic carbon $0.42 \%, \mathrm{CaCO}_{3} 2.82 \%$; available N, P, K, S $6.8,3.9,246,4.2 \mu \mathrm{g} \mathrm{g}^{-1}$, respectively; DTPA extractable $\mathrm{Zn}, \mathrm{Fe}, \mathrm{Cu}, \mathrm{Mn} 1.41,5.96,1.85$, $12.4 \mu \mathrm{g} \mathrm{g}^{-1}$, respectively. For this experiment, bacterial strain was grown in nutrient broth at $28^{\circ} \mathrm{C}$ in a rotary shaker for $48 \mathrm{~h}$ and centrifuged at 6,000 g for $10 \mathrm{~min}$. The bacterial suspension was then diluted in saline solution $(0.85 \% \mathrm{NaCl})$ to a final concentration of $10^{8} \mathrm{cfu} \mathrm{ml} \mathrm{m}^{-1}$ and the resulting suspension was used to inoculate soybean (cv JS 335) seeds. The soybean seeds were subjected to washing one time with sterile distilled water followed by surface sterilization with three-step surface sterilization procedure: a $30 \mathrm{sec}$ wash in 90 $\%$ ethanol, followed by a 3 min wash in 3.0
$\% \mathrm{NaOCl}$, and a final rinse in sterile distilled water. The experiment was conducted in a completely randomized design and consisted of forty eight sterilized cemented pots $(24$ pots inoculated and 24 pots uninoculated) and were filled with $10 \mathrm{~kg}$ soil in each pot. The moisture content was brought to field capacity before sowing of soybean seeds. Forty eight pots were sterilized with $2.0 \%$ sodium hypochlorite $(\mathrm{NaOCl})$ solution for 2 days before filling of soil. Each seed was inoculated with strain sks_bnj_1 at the rate of one ml of $10^{8} \mathrm{cfu} \mathrm{ml} \mathrm{m}^{-1}$ and two seeds per pot were sown during kharif 2005 (rainy season, June-September); after germination, one plant was maintained in each pot. Twelve replicated pots from each treatment (total 24 pots) were sampled at $\mathrm{R}_{2}$ growth stage (full bloom, 42-45 days of plant growth) of soybean crop growth for analysis of growth and rhizosphere microbial properties. Remaining 12 replicated pots from each treatment (total 24 pots) were maintained till harvest. At $R_{2}$ stage of soybean, shoots were cut $5 \mathrm{~mm}$ above the soil surface and rhizosphere soil was collected. The soil adhered strongly to roots was considered as rhizosphere soil. Roots separated carefully from the soil, were thoroughly washed and root length was measured according to the line interception method. Root surface area was determined by using the formula: $2 / \pi v \mathrm{v}$, where $\mathrm{v}=$ volume of roots, $\mathrm{l}=$ root length assuming that root is a cylindrical tube with a constant radius (Zoysa et al, 1999). Plant samples (shoot and root) were dried at $60^{\circ}$ $\mathrm{C}$ for $72 \mathrm{~h}$ for determination of shoot and root dry weight. At maturity, seed and straw samples were collected to record seed yield and nutrient assimilation by soybean crop.

\section{Rhizosphere Soil Microbial Properties}

The rhizosphere soil samples collected at $R_{2}$ growth stage of soybean were subjected to the analysis of pertinent soil enzymes activities, auxin content, microbial respiration and microbial biomass-C. Dehydrogenase activity was measured by reduction of 2,3,5-triphenyl tetrazolium chloride (TTC) to triphenyl formzan (TPF) using colorimetric procedure of Tabatabai (1994). Acid (EC 3.1.3.2) and alkaline phosphatase (3.1.3.1) activity in rhizosphere soil samples were determined 
as described by Tabatabai (1994). Phytase activity was estimated by following the method of Ames (1966). The procedure for the estimation of phosphatases and phytase has been described in the previous section, wherein instead of culture supernatant, $1 \mathrm{~g}$ soil was used for the analyses. The enzyme activities have been expressed in pKat $\mathrm{g}^{-1}$ soil. L-tryptophan derived auxin production was assayed by the method of Sarwar et al. (1992) and expressed as mg IAA equivalents $\mathrm{g}^{-1}$ soil. Soil microbial respiration was determined by quantifying the carbon dioxide released in the process of microbial respiration during 10 days of incubation. This was done by placing $25 \mathrm{~g}$ soil sample in $1 \mathrm{~L}$ conical flask together with a smaller culture tube containing $10 \mathrm{ml}$ of $0.5 \mathrm{M} \mathrm{NaOH}$ to capture the released $\mathrm{CO}_{2}$. The absorbed $\mathrm{CO}_{2}$ was determined by back titration with $0.5 \mathrm{~N} \mathrm{HCl}$, after precipitation to the barium carbonate formed by adding barium chloride aqueous solution to the $\mathrm{NaOH}$ solution, utilizing phenolphthalein as an indicator (Anderson and Domsch, 1980). Soil microbial respiration rate was reported as $\mathrm{mg} \mathrm{CO} \mathrm{Kg}^{-1}$ soil day-1. For estimation of microbial biomass-C, field-moist soil sample containing $25 \mathrm{~g}$ soil on an oven dry basis was fumigated with ethanol-freechloroform for $24 \mathrm{~h}$ in a vacuum desiccator. Following evacuation and fumigant removal, the soil samples were extracted with $0.5 \mathrm{M}$ $\mathrm{K}_{2} \mathrm{SO}_{4}$ (1:4 soil: solution ratio) by shaking for $30 \mathrm{~min}$ on an oscillating shaker. The soil suspension was filtered through Whatman No. 42 filter paper. Non-fumigated soil samples were also extracted with $0.5 \mathrm{M}$ $\mathrm{K}_{2} \mathrm{SO}_{4}$. The data has been expressed on an oven dry basis $\left(105^{\circ} \mathrm{C}\right.$ for $\left.24 \mathrm{~h}\right)$ and represents means of triplicates. Carbon in the extract from both fumigated and nonfumigated soil samples were analyzed by dichromate digestion (Vance et al, 1987). Biomass carbon was calculated from the relationship $B c=F c / K c$, where $F c$ is the difference between extractable carbon from fumigated soil and non-fumigated soil. $K c$ is conversion factor, which is 0.45 and the value has been expressed in $\mathrm{mg} \mathrm{C} \mathrm{kg}^{-1}$ soil.

\section{Plant Analysis}

Plant samples were ground to fine powder after drying at $60^{\circ} \mathrm{C}$ for $48 \mathrm{~h}$. The fine powders were used to determine the nutrient concentration in seed and straw of soybean. The nitrogen concentration in sulphuric acid digested samples was determined using the standard Kjeldahl digestion and distilled through Kjeltec Auto 1030 Analyzer (Tecator, Sweden). For the estimation of phosphorus, potassium, sulphur and micronutrients, the powder samples were digested in a 5:4 mixture of nitric acid and perchloric acid. The phosphorus was estimated by vanadomolybdate method, potassium by flame photometry, sulphur by turbidimetry method (Baruah and Barthakur, 1999) and micronutrients by atomic absorption spectrophotometer (GBC Savanta AA Series).

\section{Statistical Analysis}

The data was analyzed by using SAS statistical software (ver.9.2; SAS Institute., Cary, NC). One way analysis of variance (ANOVA) was carried out with the ANOVA procedure in SAS enterprise guide 4.2 and the least significant differences (LSD: $\mathrm{P}=$ 0.05 or 0.01 ) and Duncan multiple range test (DMRT) were used to separate the treatment means. Pearson correlation between rhizosphere microbial properties, growth and nutrient acquisition parameters was also carried out using SAS.

\section{Results}

\section{Cultural, Chemotaxonomic and Molecular Characteristics of Test Bacterium}

During the course of recovery of pathogenic fungi associated with soybean roots infected with black rot complex, a predominantly occurring antagonistic bacterial isolate along with fungal isolates comprising of Trichoderma harzianum MTCC 7105, T. lactea MTCC 7110, Scerotium rolfsii, Sclerotinia sp MTCC7114, Fusarium nivale MTCC7111 were recovered (Fig. 1). This bacterial isolate was subjected to further characterization for its identification, plant growth- promoting traits and nutrient acquisition by soybean. The colonies of the selected isolate were small, fast growing, wrinkle, dull and dry, white, irregular, lobate and flat on NA medium incubated at $28^{\circ} \mathrm{C}$ for $48 \mathrm{~h}$. Microscopic examination revealed that the isolate was Gram positive, 
endospore-forming and the cells were rod shaped and in chains (Fig. 1). It was able to grow between $15-45^{\circ} \mathrm{C}$ with an optimum growth at $32^{\circ} \mathrm{C}$. The isolate grew at a pH of 6.0 and could tolerate sodium chloride concentration up to $10 \%$. The isolate was positive for catalase, oxidase, nitrate reductase, Voges Proskauer, citrate utilization, starch- and casein- hydrolysis and found negative for methyl red and arginine dihydrolysis tests. The carbohydrate utilization pattern showed utilization of glucose, lactose, starch, casein, sorbitol, glycogen and L-arabinose resulting in acid production, while negative reaction was observed with respect to utilization of galactose, D-arbinose, L-xylose, rhamnose,
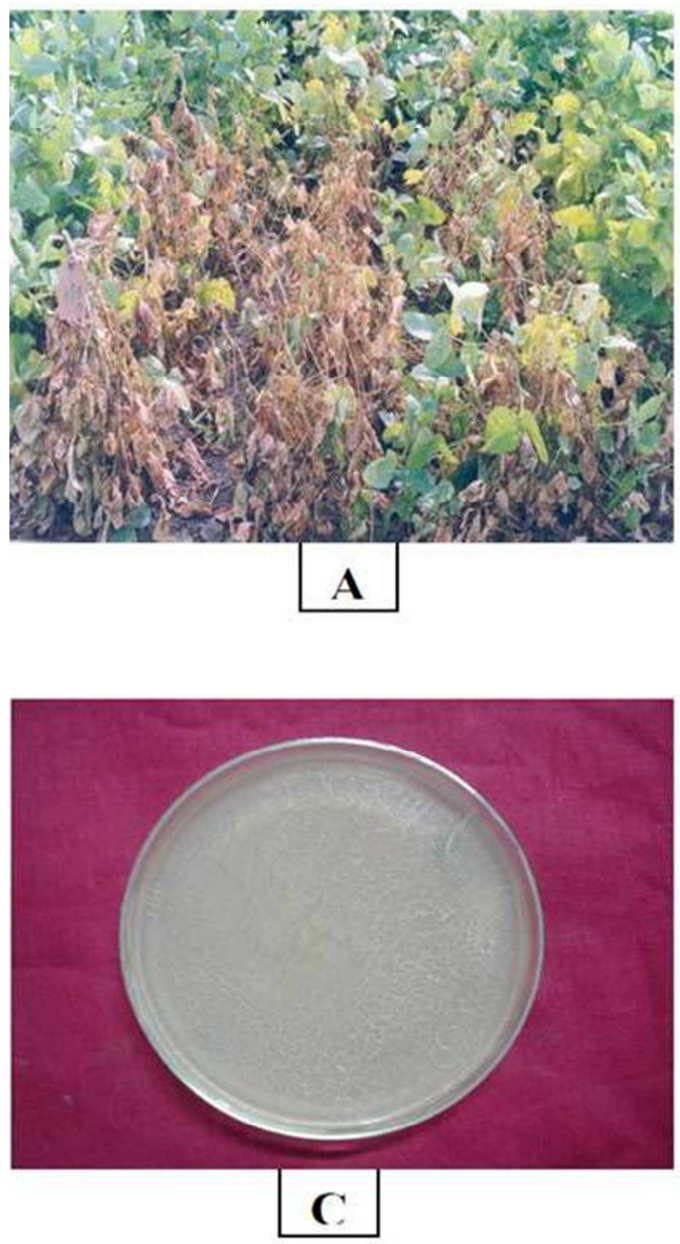

inulin, trehlose and $\mathrm{N}$-acetylglucosamine (Table 1). The above features indicated that the isolate belonged to the genus Bacillus. The identity was further confirmed by FAMEs profiling and molecular approach. The whole cell fatty acid profile of the isolate showed presence of $\mathrm{C}_{15: 0}(25.50 \%)$ anteiso- $\mathrm{C}_{15: 0,}(34.30 \%)$ as major fatty acids and iso- $\mathrm{C}_{14: 0}(2.15 \%)$ iso- $\mathrm{C}_{16: 0}(5.40 \%)$, iso- $\mathrm{C}_{17: 0,}(9.07 \%)$ anteiso- $\mathrm{C}_{17: 0,},(8.11 \%)$ as minor ones : these features confirmed that it belonged to the genus Bacillus (Table1). The nucleotides sequence (>500 bp) of $16 \mathrm{~S}$ rRNA gene of the isolate showed $98.7 \%$ similarity to Bacillus amyloliquefaciens and was submitted to NCBI GenBank with accession number of AY 932823 (Table 1).
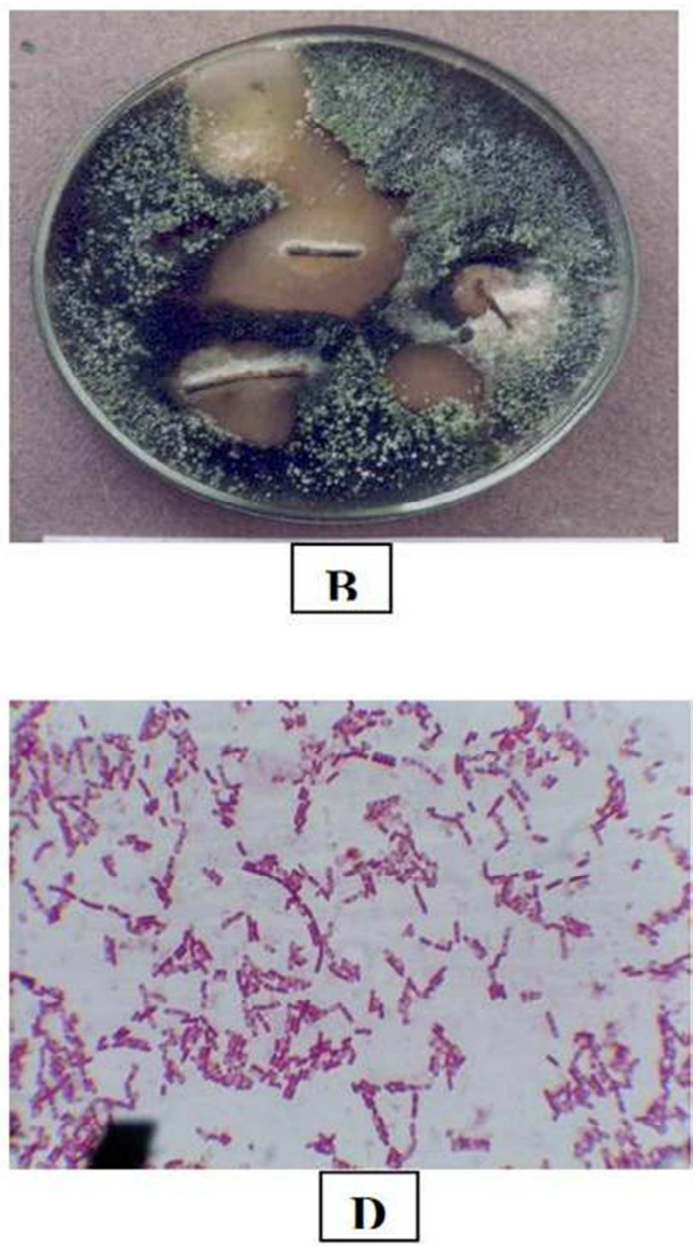

Fig.1: Isolation of Antagonistic B. amyloliquefaciens Strain Sks_Bnj_1 From Soybean Disease Complex Appeared in Kharif 2004. [A: Soybean Disease Complex; B: Isolation of Bacillus Isolate; C: Bacillus Isolate; D: Gram Positive Cells of Bacillus Sp Strain sks_bnj_1] 
Table 1: Morphological, Biochemical, Physiological and Molecular Characteristics of $B$ amyloliquefaciens Strain sks_bnj_1

\begin{tabular}{|c|c|c|}
\hline \multicolumn{2}{|l|}{ Characteristics } & \multirow{2}{*}{$\begin{array}{l}\text { B. amyloliquefiaciens. strain sks_bnj__1 } \\
\text { Wrinkle, dull, dry }\end{array}$} \\
\hline \multirow[t]{6}{*}{ Morphological } & Appearance & \\
\hline & Pigmentation & White \\
\hline & Size & $2 \mathrm{~mm}$ \\
\hline & Form & Irregular \\
\hline & Margin & Lobate \\
\hline & Elevation & Flat \\
\hline \multicolumn{2}{|l|}{ Gram's reaction } & Gram positive \\
\hline \multicolumn{2}{|l|}{ Endospore formation } & + \\
\hline \multicolumn{2}{|l|}{ Growth at pH 6.0} & + \\
\hline Maximum growth temp & $45^{\circ} \mathrm{C}$ & + \\
\hline Minimum growth temp & $15^{\circ} \mathrm{C}$ & + \\
\hline \multirow{5}{*}{$\begin{array}{l}\text { Growth in presence } \\
\mathrm{NaCl}\end{array}$} & $3 \%$ & + \\
\hline & $5 \%$ & + \\
\hline & $7 \%$ & + \\
\hline & $10 \%$ & + \\
\hline & $15 \%$ & _- \\
\hline \multicolumn{2}{|l|}{ Catalase } & + \\
\hline \multicolumn{2}{|l|}{ Oxidase } & + \\
\hline \multicolumn{2}{|l|}{ Nitrate reduced to nitrite } & + \\
\hline \multicolumn{2}{|l|}{ Arginine dihydrolase } & - \\
\hline \multicolumn{2}{|l|}{ Voges Proskauer } & + \\
\hline \multicolumn{2}{|l|}{ Citrate utilization } & + \\
\hline \multicolumn{2}{|l|}{ Triple sugar agar } & AlS, AlB \\
\hline \multicolumn{2}{|l|}{ Methyl red } & - \\
\hline \multicolumn{2}{|l|}{ Starch hydrolysis } & + \\
\hline \multicolumn{2}{|l|}{ Casein hydrolysis } & + \\
\hline \multirow[t]{14}{*}{ Acid production from } & Glucose & + \\
\hline & Lactose & + \\
\hline & Galactose & - \\
\hline & D-Arabinose & - \\
\hline & Starch & + \\
\hline & Casein & + \\
\hline & Inulin & - \\
\hline & L-xylose & _ \\
\hline & Rhamnose & - \\
\hline & Sorbitol & + \\
\hline & Glycogen & + \\
\hline & Trehlose & _ \\
\hline & L-arabinose & + \\
\hline & $\mathrm{N}$-acetylglocosamine & - \\
\hline \multicolumn{2}{|l|}{ Predominant fatty acids } & $\begin{array}{l}\mathrm{C}_{14: 0}(1.53 \%) ; \text { Iso- } \mathrm{C}_{14: 0}(2.15 \%) ; \text { Iso- } \mathrm{C}_{15: 0} \\
(25.50 \%) \text { and anteiso- } \mathrm{C}_{15: 0}(34.30 \%) ; \mathrm{C}_{16: 0} \\
(7.32 \%) ; \mathrm{Iso} \mathrm{C}_{16: 0}(5.40 \%) ; \mathrm{C}_{16: 0} 1 \omega 11 \mathrm{c}(2.87 \\
\%) ; \mathrm{Iso}_{17: 0}(9.07 \%) ; \mathrm{C}_{17: 0}(5.21 .23 \%) ; \\
\text { anteiso- } \mathrm{C}_{17: 0}(8.11 \%)\end{array}$ \\
\hline \multicolumn{2}{|c|}{$\begin{array}{l}\text { Identification of bacterium on partial 16S rDNA } \\
\text { sequencing (Identity \%: } 98.7 \% \text { ) }\end{array}$} & $\begin{array}{l}\text { Bacillus amyloliquefaciens strain sks_bnj_1 } \\
\text { (Accession No. AY932823) }\end{array}$ \\
\hline
\end{tabular}




\section{Plant Growth-Promoting Traits of $B$. amyloliquefaciens Strain sks_bnj_1}

Multiple plant growth-promoting traits of $B$. amyloliquefaciens strain sks_bnj_1 are given in Table 2. The strain was positive for siderophore production as discernible by yellow to orange halo formation (15.45 mm) against a blue background on CAS agar medium (Fig. 2). The CAS-shuttle assay revealed that the strain produced $82.35 \%$ siderophore units. It was observed that the strain formed purple colour zone on 0-CAS indicating production of catecholate type of siderophore which was further confirmed by Arrow's test (Table 2). The halo formation on PDA and King's B agar (Himedia, Mumbai, India) supplemented with CAS was more pronounced as compared to nutrient agar suggesting that appropriate culture medium should be employed to detect this functional property. The perusal of the data on production of IAA like compounds revealed that the strain
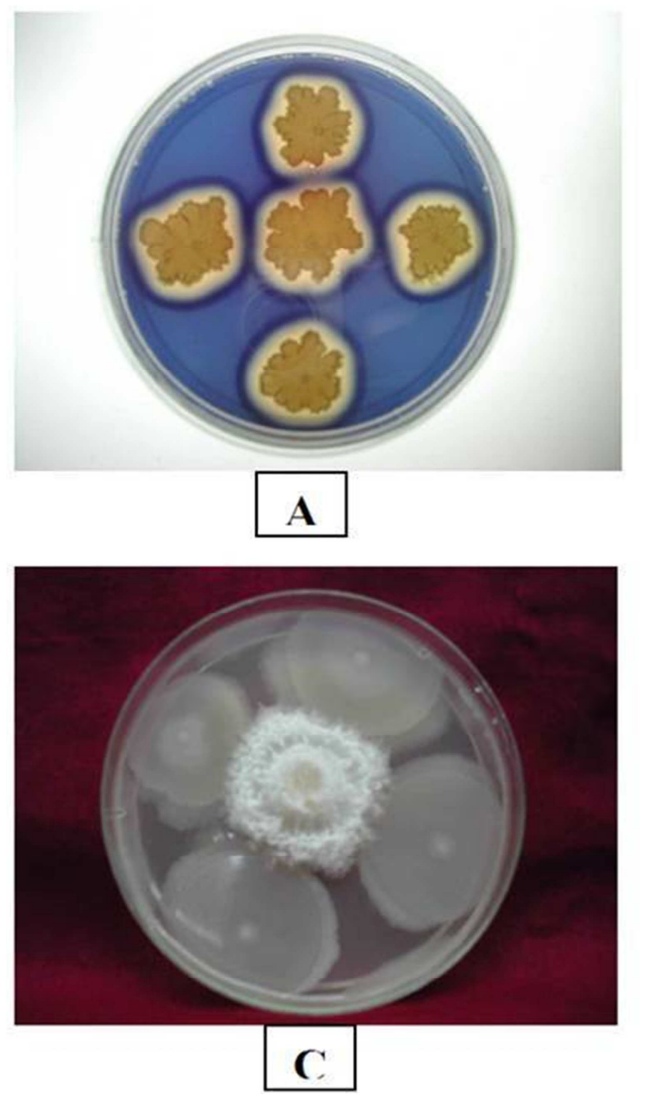

produced $18.54 \mu \mathrm{g} \mathrm{ml} \mathrm{ml}^{-1}$ IAA-equivalents in the presence of L-tryptophan. The strain was found positive towards ACC deaminase activity and produced $358.0 \quad \mathrm{NH}_{4}{ }^{+} \mathrm{mg}^{-1}$ protein $\mathrm{h}^{-1}$. The strain also had an innate property to produce acid and alkaline phosphatase, and phytase activities in the liquid medium which indicated its potential towards mineral-P solubilization and organic-P mineralization. Zinc solubilization assay revealed that the strain solubilized insoluble zinc in vitro supplemented separately with three zinc compounds like zinc oxide, zinc phosphate and zinc carbonate (Table 2). The perusal of the data indicates that the strain produced both cyanide and cellulase. The strain inhibited soil-borne phytopathogens namely Sclerotium rolfsii, Fusarium nivale MTCC7111 and Sclerotinia spp MTCC7114. The strain inhibited Sclerotinia more conspicuously as compared to the other fungal isolates included in the study (Fig. 2).
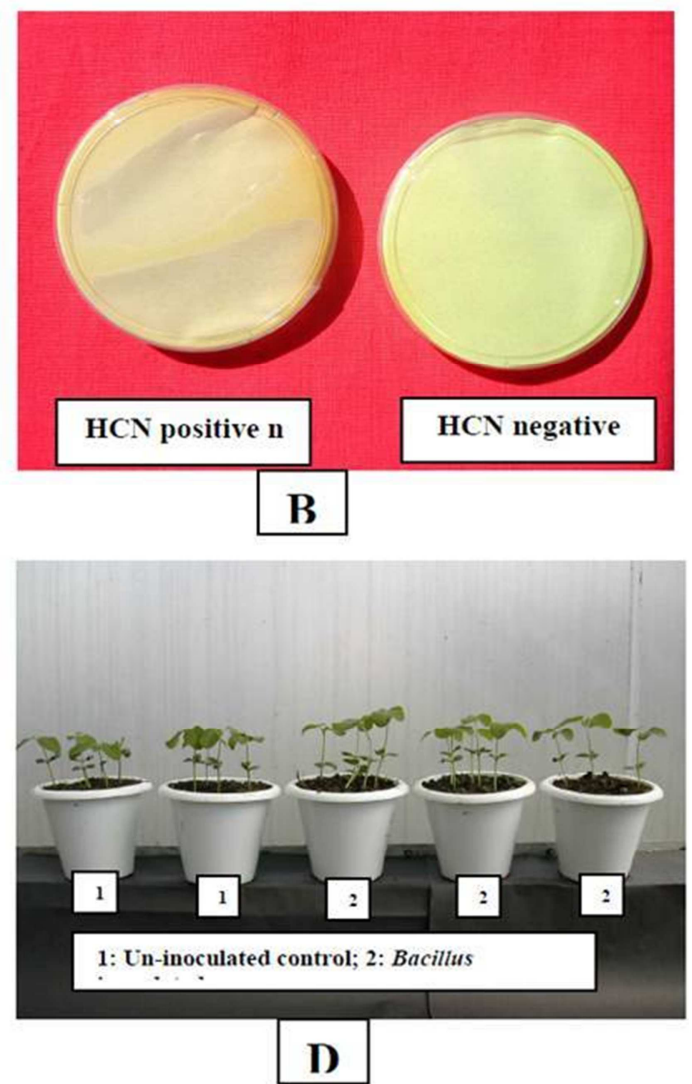

Fig. 2: Plant Growth-Promotion and Biocontrol Traits of B. amyloliquefaciens Strain sks_bnj_1. [A: Siderophore Production; B: HCN Production; C: Antagonism against Sclerotinia Sp; D: Seedling Growth Promotion]. 
Table 2: Plant Growth-Promoting Traits of B. amyloliquefaciens Strain sks_bnj_1

\begin{tabular}{|c|c|c|}
\hline \multicolumn{2}{|l|}{ Characteristics } & Strain sks_bnj_1 \\
\hline \multicolumn{2}{|c|}{ Siderophore production (diameter in $\mathrm{mm}$ ) } & $15.45 \pm 0.49$ \\
\hline \multicolumn{2}{|c|}{ Reaction on Overlay-CAS (O-CAS) } & Purple halo zone \\
\hline \multicolumn{2}{|c|}{ Siderophore production ( \% siderophore units) } & $82.34 \pm 0.31$ \\
\hline \multirow[t]{4}{*}{ Types of siderophore } & Arnow's assay & + \\
\hline & Atkin's test & - \\
\hline & Tetrazolium test & - \\
\hline & $\mathrm{FeCl}_{3}$ test & + \\
\hline \multicolumn{2}{|l|}{ IAA-like compounds $\left(\mu \mathrm{g} \mathrm{ml}^{-1}\right)$} & $18.54 \pm 0.19$ \\
\hline \multicolumn{2}{|c|}{ ACC deaminase activity $\left(\mathrm{NH}_{4}{ }^{+} \mathrm{mg}^{-1} \mathrm{~h}^{-1}\right)$} & $358.0 \pm 8.69$ \\
\hline \multicolumn{2}{|c|}{ Acid phosphate activity ((pKat ml $\left.\mathrm{m}^{-1}\right)$} & $191.54 \pm 7.71$ \\
\hline \multicolumn{2}{|c|}{ Alkaline phosphate activity ((pKat ml-1) } & $281.45 \pm 9.31$ \\
\hline \multicolumn{2}{|c|}{ Phytase activity (pKat $\mathrm{ml}^{-1}$ ) } & $423.4 \pm 12.59$ \\
\hline \multirow{3}{*}{$\begin{array}{l}\text { Insoluble zinc-solubilization } \\
\left(\left(\mu \mathrm{g} \mathrm{Zn} \mathrm{ml}^{-1}\right)\right.\end{array}$} & Zinc oxide & $2.59 \pm 0.03$ \\
\hline & Zinc phosphate & $3.71 \pm 0.09$ \\
\hline & Zinc carbonate & $2.12 \pm 0.07$ \\
\hline \multicolumn{2}{|l|}{ Hydrogen cyanide production } & + \\
\hline \multicolumn{2}{|l|}{ Cellulase production } & + \\
\hline \multicolumn{2}{|c|}{$\begin{array}{l}\text { Antagonism towards Sclerotium rolfsii, Sclerotinia sp, } \\
\text { Fusarium nivale }\end{array}$} & + \\
\hline
\end{tabular}

Soil Biological Properties and Growth, Yield and Nutrient Assimilation by Soybean

The influence of B. amyloliquefaciens strain sks_bnj_1 on growth, rhizosphere properties, and nutrient acquisition was carried out under microcosm conditions with soybean as a test crop. Inoculation with this strain significantly enhanced enzyme activities, microbial respiration, microbial biomass-C and IAA-like compounds in the rhizosphere soil of soybean as compared to un-inoculated control. It was observed that the activities of dehydrogenase, acid phosphatase, alkaline phosphatase and phytase; microbial respiration, microbial biomass- $\mathrm{C}$ and IAA-like compounds production were increased up to $34.02 \%$, $44.86 \%, 27.93 \%, 11.40 \%, 19.07 \%, 26.85$ $\%, 23.71 \%$, respectively, over un-inoculated control (Table 3). The inoculation with the strain sks_bnj_1 significantly enhanced seedling height, shoot dry matter accumulation, root surface area and seed yield by $11.5 \%, 25.13 \%, 17.91 \%$ and $23.43 \%$, respectively (Table 4; Fig.2) over un-inoculated control. In this study, we did not observe incidence of any disease throughout the experimentation.

Table 3: Changes in Enzyme Activities, IAA-Like Compounds, Microbial Respiration and Biomass-C of Rhizosphere Soils as Influenced by Inoculation of B. amyloliquefaciens Strain sks_bnj_1

\begin{tabular}{|c|c|c|c|}
\hline Properties & Strain sks_bnj_1 & Un-inoculated control & LSD $(P<0.01)$ \\
\hline Dehydrogenase activity (pKat g-1 soil) & $5.16 \pm 0.38^{\mathrm{a}}$ & $3.85 \pm 0.43^{\mathrm{b}}$ & 0.47 \\
\hline Acid phosphatase activity (pKat $\mathrm{g}^{-1}$ soil) & $45.56 \pm 2.62^{\mathrm{a}}$ & $31.45 \pm 3.52^{b}$ & 3.57 \\
\hline Alkaline phosphatase activity (pKat $\mathrm{g}^{-1}$ soil) & $74.78 \pm 6.69^{a}$ & $58.45 \pm 4.88^{\mathrm{b}}$ & 6.75 \\
\hline Phytase activity (pKat g ${ }^{-1}$ soil) & $211.40 \pm 21.53^{\mathrm{a}}$ & $189.75 \pm 11.29^{b}$ & 19.80 \\
\hline IAA-like compounds ( $\mu$ g IAA g-1 soil) & $192.60 \pm 23.31^{\mathrm{a}}$ & $155.68 \pm 7.35^{\mathrm{b}}$ & 19.86 \\
\hline Microbial respiration $\left(\mathrm{mg} \mathrm{CO}_{2} \mathrm{~kg}^{-1}\right.$ soil $\left.^{-1} \mathrm{~d}^{-1}\right)$ & $23.03 \pm 1.94^{\mathrm{a}}$ & $19.34 \pm 2.46^{\mathrm{b}}$ & 2.55 \\
\hline Microbial biomass-C (mg C kg-1 soil) & $235.45 \pm 13.91^{\mathrm{a}}$ & $185.60 \pm 10.34^{b}$ & 13.92 \\
\hline
\end{tabular}

Means \pm S.D. (standard deviation) sharing the same letter within a row do not differ significantly according DMRT $(\mathrm{P}<0.01)$.

Average of 12 replicated pots with one plant per pot; pKat: picoKatal 
Table 4: Growth, Yield and Nutrient Acquisition by Soybean after Inoculation of $B$. amyloliquefaciens Strain sks_bnj_1

\begin{tabular}{|c|c|c|c|}
\hline Parameters & Strain sks_bnj_1 & Un-inoculated control & LSD $(\mathrm{P}<0.01)$ \\
\hline $\begin{array}{l}\text { Shoot dry weight (g } \\
\left.\text { plant }^{-1}\right)^{*}\end{array}$ & $4.48 \pm 0.50^{\mathrm{a}}$ & $3.58 \pm 0.30^{\mathrm{b}}$ & 0.48 \\
\hline $\begin{array}{l}\text { Root surface area } \\
\left(\mathrm{cm}^{3} / \mathrm{pl}\right)^{*}\end{array}$ & $156.88 \pm 7.96^{\mathrm{a}}$ & $133.04 \pm 6.28^{\mathrm{b}}$ & 8.28 \\
\hline Seed yield (g plant ${ }^{-1}$ ) & $9.06 \pm 0.91^{\mathrm{a}}$ & $7.34 \pm 0.33^{\mathrm{b}}$ & 0.75 \\
\hline \multicolumn{4}{|c|}{ Nutrient content in seed } \\
\hline Nitrogen $(\mathrm{N})$ & $60.07 \pm 1.71^{\mathrm{a}}$ & $59.63 \pm 7.02^{\mathrm{a}}$ & NS \\
\hline Phosphorus (P) & $3.74 \pm 0.44^{\mathrm{a}}$ & $3.10 \pm 0.26^{b}$ & 0.42 \\
\hline Potassium (K) & $15.69 \pm 0.96^{\mathrm{a}}$ & $13.42 \pm 0.69^{b}$ & 0.96 \\
\hline Sulphur (S) & $2.51 \pm 0.31^{\mathrm{a}}$ & $2.39 \pm 0.27^{a}$ & NS \\
\hline Zinc (Zn) & $54.35 \pm 6.22^{\mathrm{a}}$ & $53.30 \pm 6.97 \mathrm{a}$ & NS \\
\hline Iron $(\mathrm{Fe})$ & $213.85 \pm 29.68^{a}$ & $182.65 \pm 13.16^{b}$ & 26.41 \\
\hline Manganese (Mn) & $27.57 \pm 3.39 \mathrm{a}$ & $22.87 \pm 1.56^{\mathrm{b}}$ & 3.44 \\
\hline Copper $(\mathrm{Cu})$ & $12.68 \pm 2.35^{\mathrm{a}}$ & $10.45 \pm 1.80^{\mathrm{a}}$ & NS \\
\hline \multicolumn{4}{|c|}{ Nutrient content in straw } \\
\hline Nitrogen $(\mathrm{N})$ & $8.75 \pm 0.74^{\mathrm{a}}$ & $8.45 \pm 0.59^{a}$ & NS \\
\hline Phosphorus (P) & $2.12 \pm 0.29^{a}$ & $1.54 \pm 0.19 \mathrm{~b}$ & 0.28 \\
\hline Potassium (K) & $13.46 \pm 0.93^{\mathrm{a}}$ & $10.55 \pm 0.94 \mathrm{~b}$ & 1.07 \\
\hline Sulphur (S) & $1.87 \pm 0.22^{\mathrm{a}}$ & $1.54 \pm 0.18^{b}$ & 0.24 \\
\hline Zinc $(\mathrm{Zn})$ & $18.56 \pm 1.39 \mathrm{a}$ & $12.87 \pm 0.88^{\mathrm{b}}$ & 1.34 \\
\hline Iron $(\mathrm{Fe})$ & $146.81 \pm 8.89^{a}$ & $104.44 \pm 6.99 \mathrm{~b}$ & 9.16 \\
\hline Manganese (Mn) & $19.96 \pm 2.23^{\mathrm{a}}$ & $15.58 \pm 1.61^{\mathrm{b}}$ & 2.23 \\
\hline Copper $(\mathrm{Cu})$ & $5.53 \pm 0.89 \mathrm{a}$ & $4.67 \pm 0.63^{a}$ & NS \\
\hline
\end{tabular}

Means \pm S.D. (standard deviation) sharing the same letter within a row do not differ significantly according DMRT $(\mathrm{P}<0.01)$

* Sampled at $\mathrm{R}_{2}$ stage of soybean growth; N, P, K, S are expressed in $\mathrm{mg} \mathrm{g}^{-1}$ while Zn, Fe, Mn, Cu were expressed in ( $\mu$ g g-1 $)$; Average of 12 replicated pots with one plant per pot

The perusal of the data on nitrogen assimilation consequent to inoculation of $B$. amyloliquefaciens strain sks_bnj_1 revealed that its accumulation in seed and straw did not significantly increase as compared to un-inoculated control. However, phosphorus and potassium accumulation by seed and straw were significantly increased with the inoculation. The increase in $\mathrm{P}$ and $\mathrm{K}$ accumulation was 20.64 and $16.91 \%$, respectively, while $\mathrm{P}, \mathrm{K}$ and $\mathrm{S}$ in straw increased by 37.66, 27.58 and $21.42 \%$, respectively, over un-inoculated control. Similarly, there was also an increase in the micronutrients accumulation in seed and straw with the inoculation. The percent increase of $\mathrm{Zn}, \mathrm{Fe}, \mathrm{Mn}$ and $\mathrm{Cu}$ content in soybean seeds with inoculation was $1.96 \%$, $17.08 \%, 20.55 \%$ and $21.33 \%$, respectively, while in straw $44.21 \%, 40.56 \%, 28.11 \%$, $18.41 \%$, respectively, over un-inoculated control. The relationship between rhizosphere properties and nutrient assimilation by soybean with inoculation indicated that enzyme activities, IAA-like compounds, microbial respiration generally influenced assimilation of $\mathrm{P}, \mathrm{K}, \mathrm{Fe}, \mathrm{Mn}$ and $\mathrm{Cu}$ by soybean seed, while almost all the rhizosphere properties influenced nutrient assimilation in soybean straw with $\mathrm{N}$ being an exception (data not shown). The results elaborated above established that the $B$. amyloliquefaciens strain sks_bnj_1 is a bacterium possessing multifarious plant growth-promoting traits.

\section{Discussion}

Many examples of plant growth-promoting microorganisms in mediating nutrient mobilization and involvement in various biochemical processes have been reported (Basak and Biswas, 2010; Marschner et al, 2011). The present study was initiated to isolate and characterize niche-based rhizobacteria possessing multiple plant growth -promoting traits with purpose to stimulate nutrient mobilization and 
assimilation by soybean crop. The genus Bacillus was characterized based on the distinguishing features such as Gram positive, aerobic, endospore producing, catalase-positive, rod-shaped bacteria (Reddy et al, 2008; Suresh et al, 2011) and was also observed in the test isolate. An overview of the morphological and biochemical traits indicate that the selected strain belong putatively to Bacillus sp as the traits closely mirrored to the features reported by other researchers (Sneath et al, 1986; Koneman et al, 1992). The whole cell fatty acid profile confirmed that the isolate belonged to Bacillus due to predominance of iso- $\mathrm{C}_{15: 0}$ and anteiso- $\mathrm{C}_{15: 0}$ which are considered signature fatty acids for Bacillus (Suresh et al, 2011). The identification of the isolate was eventually confirmed through sequencing of 16S rRNA gene and found to belong to B. amyloliquefaciens. The sequence was submitted to NCBI with an accession no AY932823. The presence of many plant associated Bacillus species in the rhizosphere of soybean and other crops have been reported from several countries (Krebs et al, 1998; Reva et al, 2004; Prathuangwong and Buensateai, 2007). The strains of Bacillus are of special interest because they are endospore forming that allow them to resist adverse environmental conditions and persist in the environment for an appreciable period of time, can be mass produced, and permit easy formulation and storage (Ramirez and Kloepper, 2010).

In the current study, strain sks_bnj_1 exhibited multiple growth-promoting traits in vitro. It has also been reported that Bacillus sp. RM-2 possess multitude of PGP traits isolated from arid region of India and enhance plant growth-promotion of many arid crops (Minaxi et al, 2011). The strain sks_bnj_1 induced production of significant amounts of IAA-like compounds in the presence of L-tryptophan (L-TRP), a precursor of IAA biosynthesis and is in agreement with the study of Idriss and coworkers (2007). Production of IAA-like compounds was found more common in the strains belonging to B. amyloliquefaciens, $B$. megaterium and B. simplex (Erturk et al, 2010; Idriss et al, 2007). IAA is the most common growth regulator produced by PGPR and is important for improved plant growth, including root development (Helman et al, 2011). Siderophores are iron chelator synthesized by rhizobacteria and play an important role in promoting plant growth either directly, by Fe supplies to the plant, or indirectly, by limiting the $\mathrm{Fe}$ availability to pathogens (Glick 1995; Bevivino et al, 1998). In fact, many studies have reported that Bacillus species are potent siderophore producer and thus may promote plant growth and act as plant pathogen antagonists (Yu et al, 2011; Zhao et al, 2011). In Vertisols of central India, soybean crop is prone to lime induced iron deficiency and possessing a trait like siderophore production may provide an alternative to alleviating iron deficiency to an appreciable extent. In the present study, $B$. amyloliquefaciens strain sks_bnj_1 produced catecholate type siderophore. This is in consonance with the study of Mullis and coworkers (1971) wherein, they observed occurrence of this type of siderophore in bacteria. It has been reported that production of ACC deaminase enzyme by rhizobacteria enables the hydrolysis of ACC resulting in reduced ethylene level in plants and is an important PGP trait for enhancing root growth (Hameeda et al, 2006). The presence of ACC deaminase trait found in this study may aid in better germination and root growth in early stages of soybean growth (Cattelan et al, 1999). The data revealed that inoculation with B. amyloliquefaciens strain sks_bnj_1 increased phosphatases and phytase activity in liquid culture medium. This is in accordance with those reported by other researchers (Oliveira et al, 2009; Fernández et al, 2012; Ribeiro and Cardoso, 2012). As plate assay is not considered a reliable indicator of solubilization or mineralization (Bashan et al, 2012), the strain was further assayed in liquid medium supplemented with three mineral zinc compounds (zinc oxide, zinc carbonate and zinc phosphate) at a concentration of $0.1 \% \mathrm{Zn}$. Among the zinc compounds, solubilization of zinc was found to be higher in zinc phosphate supplemented medium as compared to zinc oxide or zinc carbonate. This is in consonance with the findings of Saravanan et al, 2007 and Sharma et al, 2012. The zinc solubilizing potential of this strain observed in zinc carbonate supplemented medium assumes significance in terms of zinc 
nutrition to crop plants as Vertisols and associated soils are abundant in recalcitrant sources like carbonates and hydroxy carbonates of zinc. There was a significant decline in the medium $\mathrm{pH}$ inoculated with this strain over un-inoculated control. Production of $\mathrm{H}^{+}$and organic acids such as citric, oxalic acids, gluconic acid, pantoic acid and 2-ketogluconic acid appear to be the most significant mechanisms for heterotrophic zinc solubilization although some contribution may also arise from excretion of other metabolites, siderophores and $\mathrm{CO}_{2}$ from respiration, the significance of all these processes being variable and dependent on the organisms and the growth conditions (Fasim et al, 2002). Cyanogenesis and antagonism has been reported in several Gram positive and Gram negative rhizobacteria. Presence of HCN production trait in strain sks_bnj_1 is promising as cyanide production by rhizobacteria is associated with control of phytopathogens (Defago et al, 1990). Inoculation with $B$. amyloliquefaciens strain sks_bnj_1 resulted in vitro inhibition of Sclerotium rolfsii and Fusarium and is in line with the report of Prathuangwong and Buensanteai (2007), wherein they reported that $B$. amyloliquefaciens KPS46 inhibits growth of Sclerotium rolfsii, Colletotrichum truncatum, and Fusarium sp., and bacterial pustule pathogen $X$. axonopodis pv. glycines as these are the main causal organisms for soybean diseases in Thailand.

Soil enzyme activities have been used as an early and sensitive indicator to soil perturbations like, tillage, organic manure, crop rotation and microbial inoculation (Sharma et al, 2010). Inoculation with strain sks_bnj_1 increased the dehydrogenase activity significantly as compared to uninoculated control. The higher dehydrogenase activity in the rhizosphere soils with inoculation can be ascribed to the availability of a high quantity of biodegradable substrates and hence an improvement in their microbial activity. The microbial populations favored by the root exudates (intra- and extracellular enzymes) may also contribute to the stimulation of dehydrogenase activity. Similar increase in dehydrogenase activities with inoculation of plant growth promoting rhizobacteria has been reported (Kohler et al, 2007; Mäder et al, 2010; Rana et al, 2012). It was observed that inoculation of Bacillus significantly increased phosphatase and phytase activity as compared to un-inoculated control. Inoculation of strain sks_bnj_1 having higher IAA production ability might have increased root growth of soybean resulting in an increased production of acid phosphatases of plant origin. At the same time build-up of inoculants in the rhizosphere might have stimulated alkaline phosphatase activity, which is solely a contribution of microbes, whereas acid phosphatase contribution is through both microbial and plant origin. This is substantiated with the increase in dehydrogenase activity which is indicative of microbial build up. Similar increase in rhizosphere soil enzyme activities pertinent to $\mathrm{P}$ cycling with inoculation of Bacillus strains was earlier reported by Ramesh et al. (2011). Tarafdar and Marschner (1994) reported that increased root system might have resulted in an increased production of phosphatases of plant origin due to increased root surface area. This is supported by the positive and significant association between phosphatase activity and root surface area (acid phosphatase- $r=$ 0.772, $\mathrm{p}>0.001$; alkaline phosphatase- $\mathrm{r}=$ $0.743, \mathrm{p}>0.001$ ) in this study. Moreover, a significant and positive association was also observed between phosphatase activities and shoot dry weight and seed yield of soybean is an indication of positive roles of these enzymes in $\mathrm{P}$ assimilation and plant growth (data not shown). This study also indicated significant increases in rhizosphere phytase activity with the inoculation of bacterial strain sks_bnj_1. Significantly positive relationship $(\mathrm{r}=0.533$, p 0.007) was observed with root surface area. There are evidences that plant growthpromoting bacteria like Bacillus amyloliquefaciens, $B$. laevolacticus and $B$. subtilis are active phytase producers (Idriss et al, 2002; Chuang et al, 2007; Gulati et al, 2007). The potential role of soil microorganisms for increasing the availability of $\mathrm{P}$ from phytase activity and presumably by affecting the availability of phytate itself has been reported (Kerovuo et al, 1998; Ramirez and Kloepper, 2010). Inoculation of the strain sks_bnj_1 significantly increased microbial respiration and biomass-carbon. The increase in 
microbial biomass in this study assumes significance as it has a short turnover time and is highly sensitive to soil environmental conditions and disturbances, making it a useful index for diagnosing early changes in soil C stabilization and nutrient dynamics following perturbation (Joergensen and Emmerling, 2006). Similar increase in microbial biomass-C upon inoculation of Bacillus over un-inoculated control was also reported (Saini et al, 2004; Kohler et al, 2007).

Inoculation of strain sks_bnj_1 significantly increased the rhizosphere IAA-like compounds content over un-inoculated control. Moreover, rhizosphere IAA-like compounds content had a significant and positive relationship with root surface area ( $r=0.607, \mathrm{p} \mathrm{0.0016)}$, shoot dry weight $(\mathrm{r}=$ $0.567, \mathrm{p} 0.0038)$ and seed yield $(\mathrm{r}=0.756, \mathrm{p}$ $<0.001$ ) of soybean. This is in consonance with findings of Zhao et al. (2011), wherein they reported that inoculation of $B$. subtilis GY-IVI increased root biomass, total root length and total root volume of plants involving role of IAA like compounds. However, they also observed that the role of other PGP traits like siderophore and ammonia production cannot be ruled out and this is also evident in the present study. The presence of tryptophan-like compounds as a precursor for auxin biosynthesis in the root exudates stimulate IAA production and are enhanced in the presence of plant growth promoting rhizobacteria possessing this trait (Khalid et al, 2004; Kamilova et al, 2006).

The assimilation of $\mathrm{P}, \mathrm{K}, \mathrm{S}$ and micronutrients by seed and straw of soybean was increased with the inoculation of strain sks_bnj_1 as compared to uninoculated control. A number of studies have indicated that inoculation of beneficial bacteria improve plant growth, increase the soil enzyme activities (solubilize inorganic and mineralize organic compounds) that results in nutrient mobilization and acquisition by plants (Kohler et al, 2007; Ramesh et al, 2011). Ramesh et al, (2011) reported that inoculation of Bacillus strains increased phytase, phosphatase activity and P-nutrition of soybean. Reports also indicate that bacteria have a role to play in potassium solubilization, wherein the non- exchangeable $\mathrm{K}$ is released into the rhizosphere environment for its acquisition by plants (Kohler et al, 2007; Basak and Biswas, 2010). The bacterial strain sks_bnj_1 is known to solubilize insoluble zinc compounds in vitro as is observed in the present study and this might have contributed to the increased zinc mobilization and acquisition. Reports indicate that rhizobacteria belonging to the genus Bacillus solubilize insoluble zinc compounds and increase assimilation of zinc by soybean seed and straw (Sharma et al, 2012). The increase in zinc concentration in soybean seeds in the present study with inoculation assume significance considering the fact that zinc deficiency is ranked as the most important risk factor responsible for illness and death in developing world (WHO, 2002). Increased nutrient assimilation by plants inoculated with rhizobacteria has also been attributed to stimulation of better root development resulting in increased absorption of water and nutrients from the soil (Puente et al, 2004; Marschner et al, 2011).

In conclusion, the B. amyloliquefaciens strain sks_bnj_1 bearing multifarious plant growth-promoting traits was isolated from diseased roots of soybean c.v. Gaurav grown in Vertisols of central India. Inoculation of this multifaceted bacterium improved growth, yield and nutrition of soybean through the contributions of the bacteria mediated induced mechanisms/ processes in the rhizosphere of the soybean. Exhaustive field evaluation is a prerequisite to promote $B$. amyloliquefaciens strain sks_bnj_1 as broad-spectrum bioinoculant for soybean cultivated in India.

\section{Acknowledgements}

The authors wish to thank the Director, Directorate of Soybean Research, Indore, for providing the infrastructure facilities to carry out research work under IRC project No NRCS 6.5/06. Some components of this research are also part of my Ph.D work carried out at G.B. Pant University of Agriculture and Technology, Pantnagar, Uttarakhand, India. 


\section{References}

Altschul, S. F., Madden, T. L., Schaffer, A. A., Zhang, J., Zhang, Z., Miller, W. \& Lipman, D. J. (1997). "GAPPED BLAST and PSI-BLAST: A New Generation of Protein Database Search Programs," Nucleic Acids Research, 25:33893402.

Amarger. N. O., Macheret, V. \& Laguerre, G. (1997). "Rhizobium Gallicum Sp. Nov. and Rhizobium Giardinii Sp. Nov., from Phaseolus Vulgaris Nodules," International Journal of Systematic Bacteriology, 47: 9961006.

Ames, B. N. (1966). "Assay of Inorganic Phosphate, Total Phosphate and Phosphatase," Methods in Enzymology, 8: 115-118.

Anderson, J. P. E. \& Domsch, K. H. (1980). "Quantities of Plant Nutrients in the Microbial Biomass of Selected Soils," Soil Science, 130: 211-216.

Baakza, A., Vala, A. K., Dave, B. P. \& Dube, H. C. (2004). "A Comparative Study of Siderophores by Fungi from Marine and Terrestrial Habitats," Journal of Experimental Marine Biology and Ecology, 311: 1-9.

Bakker, A. W. \& Schipper, B. (1987). "Microbial Cyanide Production in the Rhizosphere in Relation to Potato Yield Reduction and Pseudomonas Spp. Mediated Plant Growth Stimulation," Soil Biology and Biochemistry, 19: 451-457.

Barea, J.- M., Pozo, M. J., Azcon, R. \& AzconAguilar, C. (2005). "Microbial Co-Operation in the Rhizosphere," Journal of Experimental Botany, 56: 1761-1778.

Baruah, T. C. \& Barthakur. H. P. (1999). A Textbook of Soil Analysis, Vikas Publishing House Pvt. Ltd., New Delhi.

Basak, B. B. \& Biswas D. R. (2010). "CoInoculation of Potassium Solubilizing and Nitrogen Fixing Bacteria on Solubilization of Waste Mica and Their Effect on Growth Promotion and Nutrient Acquisition by a Forage Crop," Biology and Fertility of Soils 46: 641-648.
Bashan, Y. \& Holguin, G. (1998). "Proposal for the Division of Plant Growth-Promoting Rhizobacteria into Two Classifications: Biocontrol-PGPB (Plant Growth-Promoting Rhizobacteria) and PGPB," Soil Biology and Biochemistry, 30:1225-1228.

Bazzicalupo, M. \& Fani, R. (1995). "The Use of RAPD for Generating Specific DNA Probes for Microorganisms," In: Clap JP (Eds) Methods in Molecular Biology, Species Diagonistic Protocols: PCR and Other Nucleic Acid Methods, Humana Press Inc., Totowa, N J, Pp 155-175.

Berg, G. (2009). "Plant-Microbe Interactions Promoting Plant Growth and Health: Perspectives for Controlled Use of Microorganisms in Agriculture," Applied Microbiology and Biotechnology, 84:11-18.

Bevivino, A., Sarrocco, S., Daimastri, C., Tabacchioni, S., Cantale, C. \& Chiarinin, L. (1998). "Characterization of a Free-Living Maize-Rhizosphere Population of Burkholderia Cepacia: Effect of Seed Treatment on Disease Suppression and Growth Promotion of Maize," FEMS Microbiology Ecology, 27:225-237.

Bhatia, V. S., Singh, P., Wani, S. P., Chauhan, G. S., Kesava Rao, A. V. R., Mishra, A. K. \& Srinivas K. (2008). "Analysis of Potential Yields and Yield Gaps of Rainfed Soybean in India Using CROPGRO-Soybean Model," Agriculture and Forest Meteorology, 148: 1252-1265.

Bradford, M. A. (1976). "A Rapid and Sensitive Method for the Quantification of Microgram Quantities of Protein Utilizing the Principle of Protein-Dye Binding," Annals of Biochemistry, 72:248-254.

Caravaca, F., Figueroa, D., Roldan, A. \& Azcon-Aguilar, C. (2003). "Alteration in the Rhizosphere Soil Properties of Afforested Rhamnus Lycioides Seedlings in Short-Term Response to Inoculation with Glomus Intraradices and Organic Amendment," Environment Management, 31: 412-420.

Cattelan, A. J., Hartel, P. G. \& Fuhrmann, J. J. (1999). "Screening for Plant GrowthPromoting Rhizobacteria to Promote Early 
Soybean Growth," Soil Science Society of America Journal, 63: 1670-1680.

Chuang, C. C., Kuo, Y. L., Chao, C. C. \& Chao, W. L. (2007). "Solubilization of Inorganic Phosphates and Plant Growth by Aspergillus Niger," Biology and Fertility of Soils, 43: 575584.

Correa, O. S., Montecchia, M. S., Berti, M. F., Fernandez Ferrari, M. C., Pucheu, N. L., Kerber, N. L. \& Garcia, A. F. (2009). "Bacillus amyloliquefaciens BNM122, a Potential Microbial Biocontrol Agent Applied on Seeds, Cause a Minor Impact on Rhizosphere and Soil Microbial Communities," Applied Soil Ecology, 41:185194.

Dastager, S. G., Deepa, C. K. \& Pandey, A. (2011). "Plant Growth Promoting Potential of Pontibacter Niistensis in Cowpea (Vigna Unguiculata (L.) Walp.)," Applied Soil Ecology, 49:250-255.

Defago, G., Berling, C.- H., Burger, U, Haas, D., Kahr, G., Keel, C., Voisard, C., Wurthner, P. \& Wuthrich, B. (1990). 'Suppression of Black Root of Tobacco by a Pseudomonas Strain: Potential Application and Mechanisms,' In: Horby D, Cook RJ, Henis Y, Ko WH, Rovira AD, Schppers B and Scotts PR (Eds) Biocontrol of Soil-Borne Plant Pathogens. CAB International, Oxon, UK, Pp 93-108.

Dupare, B. U., Billore, S. D. \& Joshi, O. P. (2010). "Farmers' Problems Associated with Cultivation of Soybean in Madhya Pradesh, India," Journal of Agricultural Sciences and Technology, 4:71-78.

Dworkin, M. \& Foster, J. W. (1958). "Experiment with Some Microorganisms Which Utilize Ethane and Hydrogen," Journal of Bacteriology, 75: 529-601.

Erturk, Y., Ercisli, S., Haznedar, A. \& Cakmakci, R. (2010). "Effects of Plant Growth Promoting Rhizobacteria (PGPR) on Rooting and Root Growth of Kiwifruit (Actinidia Deliciosa) Stem Cutting," Biological Research, 43: 91-98.

Fasim, F., Ahmed, N., Parsons, R. \& Gadd, G. M. (2002). "Solubilization of Zinc Salts by a Bacterium Isolated from the Air
Environment of a Tannery," FEMS Microbiology Letter, 213: 1-6.

Fernández, L., Agaras, B., Zalba, P., Wall, L. G. \& Valverde, C. (2012). "Pseudomonas Spp. Isolates with High Phosphate-Mobilizing Potential and Root Colonization Properties from Agricultural Bulk Soils under No-Till Management," Biology and Fertility of Soils, 48: 763-773.

Glick, B. R. (1995). "The Enhancement of Plant Growth by Free Living Bacteria," Canadian Journal of Microbiology, 41: 109117.

Gordon, S. A. \& Weber, R. P. (1951). "Colorimetric Estimation of Indole Acetic Acid," Plant Physiology, 26:192-195.

Gulati, H. K., Chadha, B. S. \& Saini, H. S. (2007). "Production and Characterization of Thermostable Alkaline Phytase and Bacillus Laevolacticus Isolated from Rhizosphere Soil," Journal of World Microbiology and Biotechnology, 34: 91-98.

Hameeda, B, Rupela, O. P., Reddy, G. \& Satyavani, K. (2006). "Application of Plant Growth-Promoting Bacteria Associated with Composts and Macrofauna for Growth Promotion of Pearl Millet (Pennisetum Glaucum L)," Biology and Fertility of Soils, 43: 221-227.

Hayat, R., Ali, S., Amara, U., Khalid, R. \& Ahmed, I. (2010). "Soil Beneficial Bacteria and Their Role in Plant Growth Promotion: A Review," Annals of Microbiology, 60: 579598.

Helman, Y., Burdman, S. \& Okon, Y. (2011). "Plant Growth Promotion by Rhizosphere Bacteria through Direct Effects," In: Rosenberg E, Gophna U (Eds) Beneficial Microorganisms in Multicellular Life Form. Heidelberg: Springer. Pp 89-103.

Holt, J. G., Kreig, N. R., Sneath, P. H. A., Stanley, J. T. \& Williams, S. T. (1994). 'Bergey's Manual of Determinative Bacteriology,' Williams and Wilkins, Baltimore, $M D$.

Idriss, E. E., Makarewicz, O., Farouk, A., Rosner, K., Greiner, R., Bochow, H., Richter, 
T. \& Borriss, R. (2002). "Extracellular Phytase Activity of Bacillus amyloliquefaciens FZB45 Contributes to Its Plant Growth-Promoting Effect," Microbiology 148: 2097-2109.

Idriss, E. E., Iglesias, D. J., Talon, M. \& Borriss, R. (2007). "Tryptophan Dependent Production of Indole-3-Acetic Acid (IAA) Affects Level of Plant Growth Promotion by Bacillus amyloliquefaciens FZB42," Molecular Plant-Microbe Interactions, 19: 619-626.

Jacobson, C. B., Pasternak, J. J. \& Glick, B. R. (1994). "Partial Purification and Characterization of 1-Aminocyclopropane1-Carboxylate Deaminase from the Plant Growth Promoting Rhizobacterium Pseudomonas Putida GR12-2," Canadian Journal of Microbiology, 40: 1019-1025.

Jacobsen, I., Leggett, M. E. \& Richardson, A. E. (2005). "Rhizosphere Microorganisms and Plant Phosphorus Uptake," In: Sims, J.T., Sharpley, A.N. (Eds.), Phosphorus: Agriculture and the Environment. American Society for Agronomy, Madison, WI, Pp 437494.

Joergensen, R. G. \& Emmerling, C. (2006). "Methods for Evaluating Human Impact on Soil Microorganisms Based on Their Activity, Biomass, and Diversity in Agricultural Soils," Journal of Plant Nutrition and Soil Science, 169: 295-309.

Kamilova, F., Kravchenko, L. V., Shaposhnikov, A. I., Makarova, N. \& Lugtenberg, B. J. J. (2006). "Effects of the Tomato Pathogen Fusarium Oxysporum F. Sp. Radicis-Lycopersici and of the Biocontrol Bacterium Pseudomonas Fluorescens WCS365 on the Composition of Organic Acids and Sugars in Tomato Root Exudates," Molecular Plant Microbe Interactions, 19:1121-26.

Kerovuo, J., Lauraeus, M., Nurminen, P., Kallckinen, N. \& Apajalahti, J. (1998). "Isolation, Characterization, Molecular Gene Cloning, and Sequencing of a Novel Phytase from Bacillus Subtilis," Applied and Environmental Microbiology, 64: 20792086.
Khalid, A., Arshad, M. \& Zahir, Z. A. (2004). "Screening Plant Growth-Promoting Rhizobacteria for Improving Growth and Yield of Wheat," Journal of Applied Microbiology, 96:473-480.

Kloepper, J. W., Liftshitz, R. \& Zablotowitcz, R. M. (1989). "Free-Living Bacterial Inocula for Enhancing Crop Productivity," Trends in Biotechnology, 7: 39-43.

Kohler, J., Caravaca, F., Carrasco, L. \& Roldan, A. (2007). "Interactions between a Plant Growth-Promoting Rhizobacterium, an AM Fungus and a Phosphate-Solubilising Fungus in the Rhizosphere of Lactuca Sativa," Applied Soil Ecology, 35: 480-487.

Koneman, E. W., Allen, S. D., Janda, W. M., Schreckenberger, P. C. \& Jr Winn, W. C. (1992). 'Color Atlas and Textbook of Diagnostic Microbiology,' 4th Edn. J.B. Lippincott Company, Philadelphia.

Koumoutsi, A., Chen, X.- H., Henne, A., Liesegang, H., Hitzeroth, G., Franke, P., Vater, J. \& Borriss, R. (2004). "Structural and Functional Characterization of Gene Clusters Directing Nonribosomal Synthesis of Bioactive Cyclic Lipopeptides in Bacillus amyloliquefaciens Strain FZB42," Journal of Bacteriology, 186:1084-1096.

Krebs, B., Hoding, B., Kubart, S., Workie, M. A., Junge, H., Schmiedeknecht, G., Grosch, R., Bochow, H. \& Hevesi, M. (1998). "Use of Bacillus Subtilis as Biocontrol Agent, I. Activities and Characterization of Bacillus Subtilis Strains," Journal of Plant Disease and Protection, 105: 181-197.

Kunitsky, C., Osterhout, G. \& Sasser, M. (2006). "Identification of Microorganisms Using Fatty Acid Methyl Ester (FAME) Analysis and MIDI Sherlock Microbial Identification System," Encyclopedia of Rapid Microbiological Methods, Vol 3: P 1-18.

Mäder, P., Kiser. F., Adholeya A, Singh, R., Uppal, H. S., Sharma, A. K., Srivastava, R., Sahai, V., Aragno, M, Wiemkein, A., Johri, B. N. \& Fried, P. M. (2010). "Inoculation of Root Microorganisms for Sustainable Wheat-Rice and Wheat-Blackgram Rotations in India," Soil Biology and Biochemistry, 43:609-619. 
Marschner, P., Crowley, D. \& Rengel, Z. (2011). "Rhizosphere Interactions between Microorganisms and Plants Govern Iron and Phosphorus Acquisition along the Root Axis E Model and Research Methods," Soil Biology and Biochemistry, 43:883-894.

Mullis, K. B., Pollack, J. R. \& Neilands, J. B. (1971). "Structure of Schizokinen, an IronTransport Compound from Bacillus Megaterium," Biochemistry, 10: 4894-4898.

Nain, L. M., Yadav, R. C. \& Saxena, J. (2011). "Characterization of Multifaceted Bacillus Sp. RM-2 for Its Use as Plant Growth Promoting Bioinoculant for Crops Grown in Semi Arid Deserts," Applied Soil Ecology, 59: 124-135.

Oliveira, C. A., Alves, V. M. C., Marriel, I. E., Gomes, E. A., Scotti, M. R., Carneiro, N. P., Guimaraes, C. T., Schaffert, R. E. \& Sa, N. M. H. (2009). "Phosphate Solubilizing Microorganisms Isolated from Rhizosphere of Maize Cultivated in an Oxisol of the Brazilian Cerrado Biome," Soil Biology and Biochemistry, 41: 1782-1787.

Payne, S. M. (1994). "Detection, Isolation and Characterization of Siderophores," Methods in Enzymology, 235: 329-344.

Perez-Miranda, S., Cabirol, N., George-Tellez, R., Zamudio-Rivera, L. S. \& Fernandez, F. J. (2007). "O-CAS: A Fast and Universal Method for Siderophore Detection," Journal of Microbiological Methods, 70:127-131.

Prathuangwong, S. \& Buensanteai, N. (2007). "Bacillus amyloliquefaciens Induced Systemic Resistance against Bacterial Pustule Pathogen with Increased Phenols, Peroxides, and 1, 3-ß-Glucanase in Soybean Plant," Acta Phytopathologia Entomologica Hungarica, 42: 321- 330.

Puente, M. E., Li, C. Y. \& Bashan, Y. (2004). "Microbial Populations and Activities in the Rhizoplane of Rock-Weathering Desert Plants. II. Growth Promotion of Cactus Seedlings," Plant Biology, 6:643-650.

Ramesh, A., Sharma, S. K., Joshi, O. P. \& Khan, I. R. (2011). "Phytase, Phosphatase Activity and P-Nutrition of Soybean as Influenced by
Inoculation of Bacillus," Indian Journal of Microbiology, 51: 94-99.

Ramirez, C. A. \& Kloepper, J. W. (2010). "Plant Growth Promotion by Bacillus amyloliquefaciens FZB45 Depends on Inoculam Rate and P-Related Soil Properties," Biology and Fertility of Soils, 46:835-844.

Rana, A., Joshi, M., Prasanna, R., Shivay, Y. S. \& Nain, L. (2012). "Biofortification of Wheat through Inoculation of Plant Growth Promoting Rhizobacteria and Cyanobacteria," European Journal of Soil Biology, 50:118-126.

Reddy, G. S. N., Uttam, A. \& Shivaji, S. (2008). "Bacillus Cecembensis Sp. Nov., Isolated from the Pindari Glacier of the Indian Himalayas," International Journal of Systematic and Evolutionary Microbiology, 58: 2330-2335.

Reva, O. N., Dixelius, C., Meijer, J. \& Priest, F. G. (2004). "Taxonomic Characterization and Plant Coloninzing Abilities of Some Bacteria Related to Bacillus amyloliquefaciens and Bacillus Subtilis," FEMS Microbiology and Ecology, 48: 249-259.

Riberio, C. M. \& Cardoso, E. J. B. N. (2012). "Isolation and Characterization of RootAssociated Growth Promoting Bactertia in Brazil Pine (Araucaria Angustifolia)," Microbiological Research, 167: 69-78.

Rosas, S. B., Avanzini, G., Carlier, E., Pasluosta, C., Pastor, N. \& Rovera, M. (2009). "Root Colonization and Growth Promotion of Wheat and Maize by Pseudomonas Aurantiaca SR1," Soil Biology and Biochemistry, 41: 1802-1806.

Saini, V. K., Bhandari, S. C. \& Tarafdar, J. C. (2004). "Comparison of Crop Yield, Soil Microbial C, N and P, N-Fixation, Nodulation and Mycorrhizal Infection in Inoculated and Non-Inoculated Sorghum and Chickpea Crops," Field Crops Research, 89: 39-47.

Saravanan, V. S., Madhaiyan, M. \& Thangaraju, M. (2007). "Solubilization of Zinc Compounds by the Diazotrophic, Plant Growth Promoting Bacterium 
Gluconacetobacter Diazotrophicus," Chemosphere, 66: 1794-1798.

Sarwar, M., Arshad, M., Martens, D. A. \& Frankenberger, W. T. Jr (1992). "Tryptophan-Dependent Biosynthesis of Auxins in Soil," Plant and Soil, 147:207-215.

Schwyn, B. \& Neilands, J. B. (1987). "Universal Chemical Assay for the Detection and Determination of Siderophores," Annals of Biochemistry, 160: 47-56.

Sharma, S. K., Johri, B. N., Ramesh, A., Joshi, O. P. \& Sai Prasad, S. V. (2011). "Selection of Plant Growth-Promoting Pseudomonas Spp. That Enhanced Productivity of SoybeanWheat Cropping System in Central India," Journal of Microbiology and Biotechnology, 21:1127-1142.

Sharma, S. K., Sharma, M. P., Ramesh, A. \& Joshi, O. P. (2012). "Characterization of ZincSolubilizing Bacillus Isolates and Their Potential to Influence Zinc Assimilation in Soybean Seeds," Journal of Microbiology and Biotechnology, 22: 352-359.

Sharma, S. K., Ramesh, A., Sharma, M. P., Joshi, O. P., Govaerts, B., Steenwerth, K. L. \& Karlen, D. L. (2010). "Microbial Community Structure and Diversity as Indicators for Evaluating Soil Quality," In: Eric Lichtfouse (Eds) Biodiversity, Biofuel, Agroforestry and Conservation Agriculture, Sustainable Agriculture Review 5, DOI 10.1007/978-90481-9513-8_11, Editor, Springer Science + Bussiness Media BV, the Netherlands, Pp 317358.

Sneath, P. H. A., Mair, N. S., Sharphe, M. E. \& Holt, J. G. (1986). Bergey's Manual of Systematic Bacteriology, Vol 2, William and Wilkins.

Sturz, A. V., Christie, B. R. \& Novak, J. (2000). "Bacterial Endophytes: Potential Role in Developing Sustainable System of Crop Production," Critical Review of Plant Sciences, 19:1-30.

Suresh, K., Sharma, R. \& Verma, D. (2011). "Characterization and Phylogenetic Diversity of Carboxymethyl Cellulase Producing Bacillus Species from a Landfill
Ecosystem," Indian Journal of Microbiology, 51: 531-535.

Tabatabai, M. A. (1994). "Soil Enzymes," In: Weaver R W, Angle J S, Bottomley PS (Eds), Methods of Soil Analysis: Microbiological and Biochemical Properties. Soil Science Society of America, Madison, Pp 775-833.

Tarafdar, J. C. \& Marschner, H. (1994). "Efficiency of VAM in Utilization of Organic Phosphorus by Wheat Plants," Soil Science and Plant Nutrition, 40: 593-600.

Teather, R. M. \& Wood, P. J. (1982). "Use of Congo Red Polysaccharide Interaction in Enumeration and Characterization of Cellulolytic Bacteria from Bovine Rumen," Applied and Environmental Microbiology, 43: 777-780.

Tilak, K. V. B. R. \& Reddy, B. S. (2006). 'Bacillus Cereus and B. Circulans-Novel Inoculants for Crops,' Current Science, 90: 642-644.

Vance, E. D., Brookes, P. C. \& Jenkinson, D. S. (1987). "An Extraction Method for Measuring Soil Microbial Biomass C," Soil Biology and Biochemistry, 19: 703-707.

World Health Organisation (WHO) (2002). 'The World Health Report 2002. Reducing Risk, Promoting Healthy Life,' Geneva.

Yu, X., Ai, C., Xin, L. \& Zhou, G. (2011). "The Siderophore-Producing Bacterium, Bacillus Subtilis CAS15, Has a Biocontrol Effect on Fusarium Wilt and Promotes the Growth of Pepper," European Journal of Soil Biology, 47:138-145.

Zhao, Q., Shen, Q., Ran, W., Xiao, T., Xu, D. \& $\mathrm{Xu}, \mathrm{Y}$. (2011). "Inoculation of Soil by Bacillus Subtilis Y-IVI Improves Plant Growth and Colonization of the Rhizosphere and Interior Tissues of Muskmelon (Cucumis Melo L.)," Biology and Fertility of Soils, 47:507-514

Zoysa, A. K. N., Loganathan, P. \& Hedley, M. J. (1999). "Phosphorus Utilization Efficiency and Depletion of Phosphate Fractions in the Rhizosphere of Three Tea (Camellia Sinensis L.) Clones," Nutrient Cycling in Agroecosystems, 53, 189-201. 